\title{
Romantic Elements in Tieck's Fairy Tale Der Blonde Eckbert: The Opposite and Unity of Reality and Illusion
}

\author{
Yali Luo \\ German Department, Southwest Jiaotong University, Chengdu, China \\ Email: 724175860@qq.com
}

How to cite this paper: Luo, Y.L. (2021) Romantic Elements in Tieck's Fairy Tale Der Blonde Eckbert. The Opposite and Unity of Reality and Illusion. Open Access Library Journal, 8: e8083.

https://doi.org/10.4236/oalib.1108083

Received: October 15, 2021

Accepted: November 8, 2021

Published: November 11, 2021

Copyright $\odot 2021$ by author(s) and Open Access Library Inc.

This work is licensed under the Creative Commons Attribution International License (CC BY 4.0).

http://creativecommons.org/licenses/by/4.0/

\begin{abstract}
Ludwig Tieck is regarded as a representative of German romantic literature, and his works include novels, novellas and fairy tales. His fairy tale Der Blonde Eckbert is one of the most important artistic fairy tales in the German Romantic period and has an important position in the history of German literature. The theme of this work is the praise of "Waldeinsamkeit", condemning behaviors against nature and criticizing the inflated desire. Tieck created an ideal world through imaginary characters, strange birds, puppies and forests, and used this to criticize the dark side of society. Based on Der Blonde Eckbert, this article uses the method of text analysis to study the relationship between reality and fantasy from two aspects. From the perspective of "Waldeinsamkeit" and the relationship between man and nature, it studies how the two are harmoniously unified.
\end{abstract}

\section{Subject Areas}

Literature

\section{Keywords}

Ludwig Tieck, Reality, Illusion, Der Blonde Eckbert

\section{Introduction}

The French Revolution that broke out in 1789 shocked the whole of Europe. The German Romantic movement was a product of the direct influence of the French Revolution. It reflects the political demands of the emerging bourgeoisie to get rid of feudal rule, strive for individual liberation, and oppose rationalism and classicism ideologically. Romanticism is a movement of intellectuals, art, and 
especially literature that took place in Europe from 1790 to 1850 . The term "romantic" first appeared at the end of the 17th century. At that time, the term was associated with the word "romanisch", referring to Romance languages such as French or Spanish. It was originally used to mean legendary, fictitious, and adventurous. The term romanticism was later used by Novalis, who was an early romantic poet. From the end of the 17 th century to the beginning of the 18th century, romantic philosophers represented by the Schlegel brothers, Novalis, and Tieck were mainly active in Jena, and gradually formed a new school, so they were called Early Romantic School, also known as Jena School. With the development of the Enlightenment, people have conducted in-depth explorations of the dark Middle Ages, and gradually changed people's views and evaluations of the middle Ages. Therefore, the German Romantics respected the Middle Ages from the very beginning, and this is also reflected in the works of early romantic poets [1]. In addition, romantic poets also prefer mysticism, such as fairy tales and fantasy scenes. For this performance, people must take into account the political environment in Germany at that time. Heine once said that for real princes, writers must give up ridicule and use other forms to get around this limitation [2]. Therefore, in view of political and social changes, romantic poets turned to dream worlds rather than revolutionary enthusiasm. Fairy tales are their favorite form. They use fairy tales to make up the world to express their inner desires. Tieck is an outstanding representative of fairy tales during the Romantic period. This article will focus on Ludwig Tieck and his fairy tales Der Blonde Eckbert.

Ludwig Tieck is a representative of early romanticism. With the development of the industrial revolution, people increasingly pursued material desires and sought power. Nature was seen as the opposite of industrial civilization. Faced with the cold reality, Tieck withdrew into the inner ideal world and looked for a return to nature. The art fairy tale offered especially the romantic poets a welcome opportunity to get rid of the fetters of reality [3]. That is why Tieck chose nature as the motif of the fairy tale in order to find consolation in the interest-oriented society. Ludwig Tieck is regarded as the founder of the German modern art fairy tale. His work Der Blonde Eckbert is the first romantic art fairy tale in Germany. In it he expresses his affection for and aversion to the destruction of nature and the expansive urge for material wealth. This article uses the method of text analysis to interpret the text from the perspective of romanticism, hoping that German literary works will receive more attention and readers will have a deeper understanding of romanticism.

\section{Summary of the Content Der Blonde Eckbert}

This work is about the story of the knight Eckbert and his wife Bertha. The couple led a secluded life in the Harz Mountains. They only have one friend named Walther. One day Bertha Walther talks about her youth: Because of the harsh treatment from her father, eight-year-old Bertha leaves home and takes 
refuge in the forest. There Bertha meets an old woman who takes Bertha into her home. They live in the wild with a bird and a dog. As Bertha grows up, she longs for elegant clothes, jewelry decorated with gemstones and marrying a knight. Finally she escapes from the forest with a vessel full of precious stones and then she strangles the bird, which always sings a fancy song. She goes back to town and later marries Eckbert. This is Bertha's story in the forest. Bertha can't remember the dog's name, but Walther suddenly pronounces the name. That's why Bertha gets sick out of fear and dies later. Then Eckbert shoots his only friend Walther. For a long time Eckbert lived all alone. Then Eckbert meets a new friend, Hugo. In the beginning they get along well, go for a walk together, visit the city's festivals together. After Eckbert tells Hugo the whole story, Hugo does not speak to Eckbert. That's why Eckbert fled the city. Eckbert meets the old woman in front of a mountain and learns the truth from the old woman, namely that she was both Walther and Hugo. In the end, he lies on the floor and is dead.

\section{Reality and Illusion as 0pposite}

At the end of the 18th century, fairy tales were generally valued as the best form of German romanticism. As the first artistic fairy tale of early German romanticism, Der Blonde Eckbert has distinctive characteristics of the times and is full of German romanticism. The element is the embodiment of Tieck's romanticism. Fairy tales are full of imagination and can even surpass the existence of the real world. Therefore, in the fairy tale, the conflict between the real world and the fantasy world is broken, and the reality and the illusion collide and merge with each other, presenting a state of opposite and unity. Starting from the subjective inner world of the characters, Tieck expresses his passion for the ideal world through the protagonist's yearning for a better life. He uses simple language and imagination to shape the characters and promote the development of the story. The author's criticism, irony and hope for the society are hidden in the author's fantasy world. Romantic writers deeply feel that the rationality promoted by classicism is a kind of shackles to literary creation, so they emphasize the absolute freedom of creation, request to break through the scope of literary depiction of reality, and put emotion and imagination in the first place. So Tieck described a lot of people's dreams. It is the description of this kind of dreams that makes fantasy and dreams conflict and oppose each other. This article will then explain how reality and illusion are opposed from two aspects: text structure and story content.

\subsection{From the Structural Perspective}

Folk tales have typical one-dimensional properties. The real world and the fantasy world are considered to be on the same level. The art fairy tale includes the description of the concrete reality and the symbolic scenes so that it has a strong sense of reality [4]. From the structural point of view, the fairy tale Der Blonde 
Eckbert adopts a framed narrative structure, which means that another story is interspersed in the frame of one story. The story of the real world is an external frame, narrated from the perspective of omniscience and omnipotence. The illusory perspective in the forest is the internal framework, telling another story. After telling the forest story, the narrative angle returned to the real world, which is the external frame. And under this kind of framed narrative structure, the timeline of story development is continuous. This narrative structure is more complicated than a single narrative method, and it is also this nested narrative method that allows reality and dreams to form a mutually opposed relationship. In the real world, ordinary people become miserable. Only in dreams can they lead an ideal life. The contrast between the two life states makes the opposite between reality and dream clearer. In the work, the two narrative levels are presented in the illusion and the real world, with obvious and opposing boundaries between the two worlds. At the beginning of the story, Eckbert lives in the real world. Initially, the illusion only exists in Bertha's memories. And Bertha's childhood, which she spends with the bird, the dog and the old woman, is an internal plot full of fantasy. The structure of the story in memory and the narrative structure of the whole fairy tale develop in parallel. The connection between illusion and reality shows opposite tendencies here. There are two aspects to her memories: escape from the real world of childhood and an idyllic world full of puzzles. In the real world, Bertha experiences poverty, hunger and strife. The forest is full of magical elements as the birds can sing and lay gems. In the beginning and in the process of the story there is a sharp contrast and clear boundaries between the two worlds. Eckbert and Bertha are real characters in fairy tales, the old woman only appears in the imagination. But at the end of the story, Eckbert and the old woman appear at the same time. At this point it is difficult to distinguish between reality and fantasy. The Blonde Eckbert starts in a concrete and realistic way and ends in a fantastic dismay [5]. In terms of narrative techniques, this article is mainly based on language narratives, but adds poetic writing techniques. The author combines the two genres of narration and poetry. In the article, the bird singing many times belongs to the genre of poetry, for example, "Waldeinsamkeit, Die mich erfreut...". At the end of the article, the author also added a dramatic element, that is, the character dialogue. Use character dialogue to uncover the mystery of the old woman, and even tell the amazing truth: Eckbert and Bertha are half-siblings. This kind of plot arrangement adds to the mysterious atmosphere of the fairy tale. In addition, it also impacts the reader's reading experience again, making the reader marvel at the fate of the protagonist in the story. So far, the conflict between reality and fantasy has been pushed to the climax. The opposite and mutual change between reality and illusion make the plot more lively and interesting. The use of flashback also increases the conflict and opposite between reality and illusion.

\subsection{From the Content Perspective}

At the end of the 18th and beginning of the 19th centuries, the development of 
the capitalist economy in European countries made progress. At that time Germany was a feudal state with political corruption and economic backwardness. With this in mind, romantic writers used their subjective imaginations to create an inner ideal world that could withstand the false real world. Romantic poets advocate the imagination, and in romantic work, imagination plays an important role [6]. Therefore, the inner life and the spiritual world described by romantic writers are closely related to the ills of social reality.

When Bertha escaped from the village and entered the forest, the story begins with the imagination. In this ideal world, the old woman is the key figure. Everything about the old woman has a mysterious coloring. There is nobody in the forest except the old woman. She appears in a black coat, walks with a stick and sings hymns. She gives Bertha bread and some wine. Where she lives is both paradises for Bertha and the dream world for Tieck. In his fantasy, Tieck goes to the imagined nature, which is in opposition to reason and reality. There are some indications that it is to be understood as a symbol of nature [7]. The old woman always seems to have a mask with a mysterious power. She is alone and lonely in the forest, but she has two magical companions: a bird and a dog. The magic bird has the talent to sing and lays an egg every day that contains a pearl or a gemstone. The dog is opposed to this because it has no unusual talent. However, the dog is very loyal and brings luck to Bertha. Tieck only selected the two animals and gave them special feelings. This is an important part of Tieck's inner world. The ideal world is not only in contrast to Bertha's real life, but also to Tieck's real society. The old woman is a representative of nature and a guide for a harmonious society. The wealth the Vogel brought with them may represent Tieck's good wishes for the development of German capitalism. Through the loyal dog, Tieck criticizes the complex interpersonal relationships in the real world and the growing greed of humanity. This mystical coloring in the work is a symbol of Tieck's spiritual world.

In Der Blonde Eckbert Tieck emphasizes the complexity and diversity of characters as well as the destruction of interpersonal relationships, so that the contrast between imaginary illusion and rational real life is intensified. Bertha is the protagonist of the fairy tales and all actions are built around her. Her story can be divided into three stages, namely: childhood with parents, escape into the forest and escape from the forest, which also make up the diversity of her character. She led a tragic childhood life and is considered a fool. Bertha's father keeps saying that she is not good for anything. All children learn something and help around the house. Only she plays the princess here [8]. When she fled her hometown, she hoped on the one hand to leave her hated life behind and on the other hand to strive for a distant and inner life. But the childhood she spent in the old woman's house was warm. With her Bertha learned to write, read and do housework. She became intelligent and lively, and mastered various skills. Bertha was accompanied by the dog and the bird. The forest was calm and life was very harmonious. Everything surprised and pleased her. The story doesn't end there, 
however. She grew up and longed for the new world and a colorful life. Not only did she steal the treasure and kill the bird, but she also starved the dog by tying it around the house. To her disappointment, the reality is not as colorful as she expected. She wants to love a prince. She makes up her own story. Already she sees herself elegantly dressed, adorned with precious stones. Princes and knights speak and dance with her. But at the beginning of the fairy tale, Tieck tells us about the appearance, character and lifestyle of the couple. It is noticeable that nothing is noticeable [9]. Eckbert is of medium height and skinny. You have no child and are often alone. Your life is very different from your imagination. In these three phases she has different personality traits, experiences and thoughts. It is these diverse properties that constantly come into conflict between reality and illusion, making the character image more vivid and the contrast between fantasy and reality more obvious.

The image of the old woman plays an important role in the story. The diversity of the figure of the old woman is particularly evident in her appearance, because Bertha found the old woman strange. She folds her old, skinny hands and prays. She looks weird [8]. In addition, the old woman often leaves the house and only comes back in the evening. Your life always seems to change, just like volatile nature. In addition, the diversity of the old woman is also reflected in her different attitudes towards Bertha. When Bertha first came she was like a gentle mother, always treating her well and believing her. When Bertha escaped, she was angry like a ruthless avenger. At the end of the fairy tale, the old woman screams angrily at Eckbert. The friendliness that the old woman shows in the forest is in stark contrast to the indifference of the avenger.

\section{Reality and Illusion as a Unit}

Tieck has always described the existence of a mysterious world in his artistic fairy tales. This world exists outside the lives and observations of ordinary people, and is secretly hidden outside the secular life, which is difficult for ordinary people to touch. In Der Blonde Eckbert, the protagonist enters this secret world for various bizarre reasons. At this point, the real world and the fantasy mystical world began to merge with each other. The "real world" and the "hidden world" existed and developed in parallel, and there was no clear boundary to distinguish the two worlds. The mystery between nature and mankind is embodied in the author's work. This mystery has no logic and thinking to explain, but is described through the tone of a child, it transcends the boundaries of the times. In this fusion of reality and fantasy, the harmonious relationship between man and nature is embodied.

In German culture, the writer's concern for forests is also obvious. The forest symbolizes the illusory world, so the theme of forest in fairy tales is almost inevitable. In the fairy tale, Tieck mentioned a concept: "Waldeinsamkeit". This is a concept unique to German. It is difficult to find a complete translation in other languages, so this article retains this concept and its explanation. One of its core 
concepts is to embrace loneliness and sadness, praise nature, and feel a sense of openness by being alone in the forest.

\subsection{Longing for the "Waldeinsamkeit"}

"Waldeinsamkeit" is the continuous motif and also the key word of the fairy tale. In 1840 Tieck's last novella "Waldeinsamkeit" was written and published. In Der Blonde Eckbert, Tieck rises this term for the first time. In Daniel Weidner's opinion, the world of "Waldeinsamkeit" is, so to speak, a doubly upside-down world. The "Waldeinsamkeit", the object of the wish, really comes true, even if in a certain way the other way round: not as a place of closeness to nature, but as a closed chamber in which nature can only be viewed through windows [10]. In this fairy tale the term "Waldeinsamkeit" is introduced through the song of a magical bird. The word itself is made up of the words "Wald" and "Einsamkeit". As Heather Sullivan points out, the concept of "Einsamkeit" has several possibilities, which can be either positive or negative depending on the situation [11]. Before we further analyze what is a positive or negative "Einsamkeit", we should see that the German romanticism also has two factions, "positive" and "negative". The former is represented by the Schlegel brothers and Novalis, while the latter is represented by Heine and Chamisso [1]. We can use Gorky's remarks to understand the difference between these two factions. "Negative" romanticism, it decorates reality, trying to compromise with reality. Or it is to make people escape from reality, fall into the abyss of their inner world, fall into the "mystery of life's destiny", fall into the thoughts of love and death. On the contrary, "positive" romanticism attempts to strengthen people's will to life and arouse people's resistance to the oppression of reality [12]. From this we can see that negative and positive romanticism are two different directions. For example, in the performance of subjective emotions, positive romantic emotions are optimistic, have a proactive attitude towards life, and dare to fight against oppression. The emotional expression of negative romanticism is deeply pessimistic, negative and decadent, despairing of life and succumbing to life. The romanticism in Germany is dominated by the negative romanticism. Tieck is one of the typical representatives of the negative romanticism.

With the help of this comparison, we now analyze the positive and negative "Waldeinsamkeit". In German culture, the forest is a very important symbol, and the Germans have a sense of awe and admiration for the forest. Before the Industrial Revolution, forests were the perfect representation of nature and the root of German survival and culture. The forest symbolizes the harmony between man and nature, the warm homeland of human society, and the state of optimism and vigorous development. In German fairy tales, forests are frequently used and given rich symbolic meaning. It can be concluded from the interpretation of forests that forests tend to be more positive. And in Der Blonde Eckbert also fits this point. In the forest, Bertha and the old woman lead a good life and enjoy the gifts of nature. The author gives his ideals to the forest scene, 
which provides people with a sense of security and belonging. Looking through the forest scene, this is the lonely, positive and harmonious side of the forest. But the emergence of the Industrial Revolution broke this harmony between man and nature and broke the traditional social order. Facing the dual impact of the industrial and political revolutions, some Germans wanted to achieve rapid development and had to accelerate deforestation. So far, human homes have been severely destroyed, and people began to feel a sense of "Einsamkeit". The negative side of the "Waldeinsamkeit" is not only the negative impact of the industrial revolution in social reality, but also a manifestation of Tieck's disappointment in national politics. This is why the word is understood in fairy tales with two meanings. The term can be understood both as the possibility of soul-satisfying and cleansing solitude and as the shrinking of forests in the course of industrialization and urbanization, both of which are incorporated into the natural environment. With the song of the magic bird, Tieck coined this catchphrase of the typically romantic glorification of the stay in the forest.

The "Waldeinsamkeit" runs through the whole work and in different parts this word symbolizes different meanings. The connection between man and nature is represented by the description of the "Waldeinsamkeit". The "Waldeinsamkeit" belongs to a special song that is sung by a strange bird with a strange voice and occurs several times in the lyrics, although the lyrics sometimes change.

For the first time the magic bird sings a wonderful song:

"Waldeinsamkeit,

Die mich erfreut,

So morgen wie heut

In ewiger Zeit,

$\mathrm{O}$ wie mich freut

Waldeinsamkeit." [8]

Actually, this song symbolizes the earlier quiet life with the old woman von Bertha, who had no selfish ideas at that time. At the same time, this song means a harmony between man and nature, in which one feels relaxation and joy as in the most pristine paradise. The first occurrence of the wonderful song is also an introduction or a hint of Bertha's simple life in the beginning. In her childhood she can only escape the cruelty of life through fantasy. In the forest your imagination is realized and everything is fine. With the old woman she felt the warmth of the family and is learning new skills. In daily life she is accompanied by the magic bird and the dog. She grows up happy in her new environment. People have achieved spiritual and material enrichment in the forest. For Bertha, the path through the forest seems to be a healing choice, because it shakes her out of her childhood unhappiness and lets her experience a new community with the old woman-in contrast to Bertha's fear at the beginning of the story. Here "Waldeinsamkeit" has a positive effect.

The story does not end here, however. Tieck is not satisfied with the happy 
ending of the folk tale, but lets the story turn into the opposite of luck. Bertha grew up and got knowledge about the world and people from books. She begins to fantasize about the new world. Everything is mixed up in her imagination. She wants to love a prince. She makes up stories for herself. She lost interest in her current life. The house is too small for her, her life too monotonous. Then she thinks of a new world again. She wants to see new and different things to people. Finally one day she leaves the forest. She does not go to the forest from which she came many years ago. She goes the other way. The magic bird suddenly sings one night. He sings a new song:

"Waldeinsamkeit,

Wie liegst du weit,

$O$ dich gereut

Ach einzige Freud.

Waldeinsamkeit." [8]

To her disappointment, the reality is not as good as she imagined. She does not meet a prince, but marries a mediocre knight. Their lives are unhappy, they have no children and they live in bondage and depression all day long. That is the punishment Bertha receives. Romantics view childhood as a precious time and a natural, innocent phase in life. Paradise is seen as a perfect state. Only the innocent children can reach this paradise. The hut of the ancients is far from the interference of the civilized world and therefore there is no conflict of interest. Although the bird lays gems, they are worthless in the forest. When Bertha imagined the outside world, she was seduced by material desires and even stole the old woman's treasure.

Tieck connects the real world with Bertha's experience. Bertha's desire for a new world symbolizes the human pursuit of material and industrial civilization. In the course of industrial modernization, the natural environment is continuously damaged and deteriorated. Human society has brought increasingly complex contradictions to the fore. The relationship between humans and the forest is no longer harmonious. But Tieck still urges people to find harmony between people and nature. Tieck criticizes and satirizes the current social situation through Bertha's story. In the "Waldeinsamkeit" there is also the negative meaning.

\subsection{Harmony between Human and Nature}

Due to the impact of industrialization, romantic poets began to hate capitalist material civilization, dislike the vulgar and ugly reality, and fear and hate large-scale industrialization. The majestic and magnificent nature and strange scenes in the distance have become the place where romantic writers place their ideals of freedom. In their writings, the beauty and sublime of nature often form a strong contrast with the ugly and vulgarity of city life. Some extraordinary characters often haunt nature or in strange and exotic environments. They advocate returning to nature, living in harmony with nature, and treating nature as 
a symbol of a mysterious power or a certain spiritual realm. In the text, Tieck tries to connect the individual and societal dream world with nature, which opposes contemporary reality. The forest is the main symbol of nature in this fairy tale. "The forest itself is not a pure forest, but the forest takes part in the development of the plot and gives people a certain quality that gives the fairy tale a different meaning." [13] In this part, Tieck expresses his affection for nature through the direct description of the landscape and the beautiful life in the forest. Bertha was really unlucky in her childhood. "Imagine the life of a child of poor people in the country." [8] Your parents have too many worries and often arguments. "What do these parents say to a child who does not learn anything practical and cannot help them with housework?" [8] Because of poverty and domestic violence, Bertha is forced to flee into the forest, where she doesn't have to endure the pressure and can seek shelter. When eight-year-old Bertha walks alone through the forest, the path is very long and she is afraid. But the fear of her father is greater. "Everything in the forest is slowly becoming friendlier. The trees, all the plants, everything is red and gold in front of Bertha." [8] Compared to her wretched childhood, Bertha leads a better life in the forest. The old woman is very nice to her. There is also a bird and a dog in the forest. They live together like family. Bertha learns to read and write with the old woman. The old woman gives Bertha a lot of books, very old books. The bird lays an egg every day. Inside is a pearl or a precious stone. Bertha can take these eggs and put them in the closet. Bertha already finds all of this quite natural. There is the first conflict between nature and man. Through this contrast, Tieck expresses the desire for nature and the ideal world. Many adjectives are used in the text to describe nature, so that the scenery described by the author and the things around it are more vivid and pictorial. If you read these words or phrases, e.g. "foggy evening" and "bright glow ..." as well as “... shivered from the wet cold", you can empathize with the scenes from that time. Through this description, Tieck directly expresses his longing for nature and his affection for a return to nature. Nature carries weight in people's lives and encloses the people who should keep this unique home in their memories forever. This natural home is an eternal paradise that people need.

In general, a certain demonic element is associated with nature [14]. Nature gives man the driving force to bring mankind to a higher level and to lead it into a civilized world. Nature is the representative of justice. In Der Blonde Eckbert, the old woman symbolizes nature and helps Bertha to escape suffering and misfortune. The primitive home of mankind is the forest. Nature represents a survival space for people. If Bertha dreams of an ideal life every day, nature also gives her the hope that this imaginary life can be realized in nature. When people stand in front of green mountains and clear water, they stand in front of nature. Nature is seen as a part of human life and the relationship between man and nature has meant harmony for a long time. On the one hand people praise and protect the natural world; on the other hand nature is shaped by the myste- 
rious impression of people. Nature is free and is a temporary refuge for people to stay away from worldly distress and remove social constraints. In reality, the human relationship is very complicated, just like that between Eckbert and his friends in this fairy tale, but they can become happy in nature, which is why people often associate nature with hope.

"The boundaries between reality and the wonderful, between nature and madness are blurred." [15] The forest leads to an unknown path. Man controls everything, but man is also in nature. There are various tests in the forest. The complicated path in the forest reflects the disorientation and confusion of human souls. Different choices also lead to different endings. In the fairy tale, Tieck shows that over time Bertha no longer likes her life. She thinks of a new world again. She goes out of the forest. That is why there is now a different conflict between man and nature in the fairy tale. In the fairy tale the old woman said: Do not do anything bad, because then the punishment will follow. It lets the dog starve and kills the magic bird. Bertha has done badly and of course the punishment follows. The bird sings the song over and over again. The louder the bird sings, the more fearful Bertha is in her heart. Often she cannot sleep all night. The world outside of the forest is not as beautiful as it was thought. Your heart is full of remorse. After Bertha told the secret, she fell ill and died. If Bertha had passed the test, she would have enjoyed the harmony of nature in this paradise forever and the old woman would have treated her as always. She would have maintained a pleasant and harmonious relationship with the old woman, the bird, the dog and all of nature. However, once the natural rules are broken, it will be punished. But the penalty for Bertha's wrongdoing is not over yet. Eckbert's life is full of suspicion, selfishness and distortion and he eventually goes mad.

This is actually a true reflection of reality. With the development of modern industry and the penetration of material desires, people begin to pursue money and power in the earthly world. The majority of people let themselves are seduced by wealth. Social life is full of oppression and inequality. Traditional morality is being replaced by interests. These acts against natural law and morality are the cause of the tragedy. If you only act according to your own will, the person himself will be destroyed in the end. The prerequisite for human life is harmony with nature and adaptation to natural law. Therefore it is very necessary and important to protect the original nature and to follow the natural law.

\section{Conclusions}

The relationship between reality and illusion in the romantic work Der Blonde Eckbert is analyzed. In the art fairy tale, the real world and the fantasy world are opposed and interwoven. The contrast between the two is mainly reflected in the mysterious elements of the forest and the diversity of the characters. By depicting the longing for the "Waldeinsamkeit" and the harmony between man and nature, the unity of reality and illusion is embodied. Tieck tries to combine real- 
ity and fantasy, truth and possibility, to shape life poetically and to return to the essence of nature.

As the famous writer Carson has shown, natural beauty plays an indispensable role in the development of the mind of any person or any society [16]. Through the song "Waldeinsamkeit", nature is viewed not only as a powerful protector, but also as a ruthless avenger in the face of the old woman's behavior. By revealing the tragic fate of Bertha, the author criticizes the excessively inflated material desires and advocates people to live a simple life; In addition, Tieck criticizes the destruction and conquest of nature by describing the worship and yearning for forests, advocates respect and protection of nature, and promotes harmony between man and nature. Tieck expressed his desire to return to nature and his aversion to violating the laws of nature in order to seek harmony between man and nature.

Indeed we must admit that German romanticism is a very important stage in history, and the study of literary works is a difficult and profound task. This article is just an analysis based on a fairy tale by Tieck, and it is impossible to glimpse the development of the entire romantic period. The author believes more in-depth and comprehensive research will be done in this field to shed a light on other scholars.

\section{Conflicts of Interest}

The author declares no conflicts of interest.

\section{References}

[1] Chen, S. (2019) On German Romanticism. Shanghai Academy of Social Science Press, Shanghai.

[2] Heine, H. (2010) Romantismus. China Legal Publishing House, Beijing.

[3] Wang, B. (2005) Literatur und Erkenntnis. Foreign Language Teaching and Research Press, Beijing.

[4] Liu, W. (2009) A Study of Fairy Tales in the Romantic Period in Germany. Beijing Institute of Technology Press, Beijing.

[5] Robert, K. (1972) Interpretation und "Relevanz": Am Beispiel von Ritter Gluck, Bergkristall, und Der blondeEckbert. Die Unterrichtspraxis/ Teaching German, 5, 56-66. https://doi.org/10.2307/3529007

[6] Shang, X. (2013) Was ist romantische Literatur. Shanghai Foreign Language Education Press, Shanghai.

[7] Otto, K. (1971) Tiecks Der blonde Eckbert: Das Märchen von Verarmung und Untergang. The German Quarterly, 44, 311-316. https://doi.org/10.2307/404396

[8] Tieck, L. (2017) Der Blonde Eckbert. Shanghai Foreign Language Education Press, Shanghai.

[9] Yang, S. (2013) Der Blonde Eckbert von Ludwig Tieck. Journal of the Graduates Sun Yat-Sen University (Social Sciences), 34, 153-164.

[10] Daniel, W. (2015) “Es ward mein Herz zur Eisenbahn”-Umschriften des Wunderbaren in Ludwig Tiecks späten Novellen. German Life and Letters, 68, 504-516. https://doi.org/10.1111/glal.12095 
[11] Erin, S. (2007) Waldeinsamkeit: Subjective Ambivalence in German Romanticism. The International Journal of the Humanities, 5, 201-210.

[12] Gorky, M. (1951) How Do I Study and Write. Jilin University Press, Changchun.

[13] Liu, A. (2014) Grimm's Fairy Tales Research. Northwest A\&F University Press, Shaanxi.

[14] Frie, T. (1973) Ein Romantisches Märchen: Der blonde Eckbert von Ludwig Tieck. Modern Language Notes, 88, 1180-1211. https://doi.org/10.2307/2907672

[15] Richard, W.K. (1970) Nature, Quest and Reality in Tieck's "Der Blonde Eckbert" and "Der Runenberg". Studies in Romanticism, 9, 176-192. https://doi.org/10.2307/25599762

[16] Brooks, P. (1972) The House of Life; Rachel Carson at Work. Houghton Mifflin, Boston. 